\title{
Influence of dietary lecithin and oils rich in n-3 polyunsaturated fatty acids (PUFA) on the fatty acid content of rat muscle and serum
}

\author{
Ewa Sawosz ${ }^{1}$, Jadwiga Chachulowa', R. Lechowski ${ }^{2}$ \\ and Sz. Fiedorowicz ${ }^{1}$ \\ ${ }^{\prime}$ Department of Animal Natrition and Feed Management, \\ Warsaw Agricultural University \\ Rakowiecka 26/30, 02-528 Warsaw, Poland \\ 'Department and Clinic of Internal Medicine. \\ Warsaw Agricultural University \\ Grochowska 272, 03-849 Warsaw, Poland
}

(Received 8 June 1998; accepted 5 July 1999)

\begin{abstract}
Forty-eight (Wistar) rats were divided into 3 groups and fed semi-synthetic diets containing various types of fat $(6 \%)$ : rape seed, linseed, or fish oil. Half of the animals in each group received lecithin $(5 \%$ of the mixture). The content of fatty acids in the serum and m. longissimus dorsi was determined, as well as serum triacylglycerides (TAG) and total cholesterol (TCh). It was found that feeding fish oil increased the percentage of cicosapentaenoic (EPA) and docosahexaenoic (DHA) acids in the serum and muscle tissue, while the addition of linseed oil increased the content of $\alpha$-linolenic acid and EPA in these tissues. The addition of lecithin raised the percentage of serum linoleic acid and decreased, EPA and DHA. TAG and TCh concentrations were much lower in the animals receiving lecithin and fish oil in their diets and, to a lesser degree, also in those receiving linseed oil, in comparison with rats fed rape seed oil.
\end{abstract}

KEY WORDS: lecithin, fatty acids, fat, rats

\section{INTRODUCTION}

It is known that the fatty acid content of some tissues of monogastric animals may be modified by diet composition. Increased incorporation of $n-3$ polyunsatu- 
rated fatty acids ( $n-3$ PUFA) into tissues using a diet containing $n-3$ fatty acids has been demonstrated in rats (Fremont et al., 1995). The beneficial effect of n-3 PUFA is related to changes in the structure of membranes and to modulation of eicosanoid synthesis.

Incorporation of dietary fatty acids into tissues can be mediated by agents such as vitamins, minerals, phospholipids. Lecithin (phosphatidylcholine; LC) is an antioxidant, a source of choline, an n-6 PUFA, and an emulsifier. Gunther (1994) showed that phospholipids increased daily gain in pigs by $11 \%$. However, in some experiments on pigs and rats the addition of lecithin to the diets did not improve the utilisation of fat, growth performance (Jones et al., 1992; Overland et al., 1993) or digestibility of fat (Sawosz ct al., 1996).

Lecithin can stimulate the activity of lecithin:cholesterol acylotrasnferase (LCAT) that catalyses the transfer of fatty acid residues from lecithin to cholesterol, i.e. esterification of cholesterol. This process can change the cholesterol content in high density lipoproteins (HDL) in relation to its content in low-density lipoproteins (LDL). The modification of cholesterol metabolism as well lecithin's other mentioned physiological functions all may affect the distribution of fatty acids and their content in fluids and tissues.

The aim of this study was to investigate the influence of supplementing diets with lecithin on the incorporation of n-3 PUFA into longissimus dorsi muscles (l.d.m) and scrum of rats.

\section{MATERIAL AND METHODS}

\section{Animals}

Forty eight male Wistar rats were divided into 6 groups $(8$ animals in each group) and kept in individual cages for 36 days. Average initial body weight was $86.6 \mathrm{~g}(81.5 \mathrm{~g}-97 \mathrm{~g})$, final weight, $188.8 \mathrm{~g}(168-207) \mathrm{g}$. At the end of the experiment the rats were anesthetized using ketamine at a dose of $50 \mathrm{mg} / \mathrm{kg} \mathrm{BW} \mathrm{i.m.}$ for blood sampling. After opening the abdominal cavity, blood was sampled from the abdominal vena cava and the rats were euthanasized by an overdose of ketamine.

\section{Feeding}

Rats received semi-purified mixtures according to NRC (1978). The diet consisted of (\%): casein, 17; sucrose, 10; wheat starch, 57.86 (52.86 in group LC); cellulose, 4; DL-methionine, 0.14; vitamins, 2 ; minerals, 3 supplemented with $6 \%$ rapeseed oil, group RO; linsecd oil, group LO; fish oil, group FO. Half of the rats 
in each group received lecithin in an amount of $5 \%$ of the mixture. Vitamin and mineral mixtures were as described by Sawosz et al., (1999). The chemical composition of the mixtures is shown in Table 1 and the percentage content of the fatty acids in dietary fats is shown in Table 2.

TABLE 1

Chemical composition of the diets, \%

\begin{tabular}{|c|c|c|c|c|c|c|}
\hline \multirow[t]{3}{*}{ llems } & \multicolumn{6}{|c|}{ Groups } \\
\hline & \multicolumn{2}{|c|}{ Rape seed oil } & \multicolumn{2}{|c|}{ Linseed oil } & \multicolumn{2}{|c|}{ Fish oil } \\
\hline & _- & Lecithin & - & Lecithin & - & Lecithin \\
\hline Dry matter & 86.3 & 86.98 & 87.02 & 86.83 & 87.51 & 86.4 \\
\hline Crude protein & 15.56 & 15.67 & 15.51 & 15.71 & 15.99 & 14.96 \\
\hline Ether extract & 5.71 & 10.69 & 5.9 & 10.78 & 6.00 & 10.35 \\
\hline Crude fibre & 1.79 & 2.92 & 3.12 & 2.64 & 2.69 & 2.53 \\
\hline $\mathrm{N}$-free extractives & 63.24 & 57.7 & 62.49 & 57.7 & 62.83 & 58.56 \\
\hline Ash & 3.72 & 3.07 & 3.12 & 2.64 & 2.69 & 2.53 \\
\hline
\end{tabular}

TABLE 2

Content of fatty acid in fat of diet, \%

\begin{tabular}{|c|c|c|c|c|}
\hline Fatty acids & Lecithin & Rape seed oil & Linseed oil & Fish oil \\
\hline $14: 0$ & 0.2 & 0.1 & 0.1 & 5.5 \\
\hline 16:0 & 19.4 & 5.0 & 5.6 & 14.2 \\
\hline $16: \ln -7$ & 0.2 & 0.3 & 0.1 & 6.9 \\
\hline $18: 0$ & 4.5 & 1.7 & 5.9 & 3.3 \\
\hline $18: \ln -9$ & 8.0 & 53.3 & 22 & 23.2 \\
\hline $18: \ln -7$ & 1.3 & 3.4 & 0.6 & 3.8 \\
\hline $18: 2 n-6$ & 58.8 & 21.4 & 16.4 & 7.2 \\
\hline $18: 3 n-3$ & 7.2 & 9.4 & 48.8 & 3.3 \\
\hline $18: 3 n-6$ & & & & 0.2 \\
\hline $20: 0$ & 0.2 & 0.6 & 0.2 & 0.3 \\
\hline $20: \ln -9$ & & 2.1 & 0.2 & 1.5 \\
\hline $20: 2 n-6$ & & 0.1 & & 0.2 \\
\hline \multicolumn{5}{|l|}{$20: 4 n-6$} \\
\hline $20: 5 n-3$ & & 0.3 & & 14.2 \\
\hline $22: \ln -9$ & & 2.0 & & 0.8 \\
\hline $22: 5 n-3$ & & & & 2.4 \\
\hline $22: 6 n-3$ & & & & 9.5 \\
\hline $24: 0$ & 0.2 & 0.1 & 0.1 & 1.1 \\
\hline $24: \ln -9$ & & 0.2 & & 1.6 \\
\hline
\end{tabular}


Analytical methods

Fatty acids were determined as described by Sawosz et al., (1999). Triacylglycerols (TAG) and total cholesterol (TCh) in serum were analyzed by enzymatic methods using Alpha Diagnostics kits (Alpha Diagnostics sp. z o.o, Warsaw, Poland). Dry matter, protein ( $\times 6.25)$, ether extract and crude fibre in the diet were determined according to AOAC (1990) using Tecator equipment.

Statistical analysis

Data were analyzed by two-way analysis of variance ANOVA, using Statgraphics 6.0 Plus software.

\section{RESULTS AND DISCUSSION}

Saturated fatty acids (SFA)

Both fish oil and soybean lecithin contained substantial amounts of palmitic acid (C16:0) (Table 2); for comparison, the average amount of this fatty acid in lard is $21.77 \%$ (Loś-Kuczera, 1990). Palmitic acid is considered to be hyperlipidemic and hypercholesterolemic (Smith et al., 1996), responsible for the atherogenic properties of fats. However, in the presented experiment, fish oil and lecithin, especially when added together to diets, were associated with a highly significant decline in serum TAG and TCh concentrations (Table 3). In rats receiving fish oil plus lecithin, the TAG concentration declined 4.9 fold, the TCh concentration 1.5 fold in comparison with animals receiving rapeseed oil. It should be stressed that the addition of fish oil concomitantly reduced TAG and TCh concentrations while increasing the percentage of palmitic acid in the serum and 1.d.m. of rats (Tables 3 and 4).

In contrast with fish oil, supplementation of palmitic acid in the form of lecithin did not increase scrum or tissue C16:0 levels, but animals fed rape seed and fish oils did show higher $\mathrm{C}$ 18:0 serum levels in response to lecithin. The clongation of palmitic acid to stearic acid is a very efficient process, which can in part explain the observed tendencies. Stearic acid is usually considered a neutral acid (Yu et al., 1995). In our experiment was observed that increasing the percentage of C18:0 in serum lipids was proportional to decreasing the TAG concentration. In the studies of other authors (Jones et al., 1992) it was found that lecithin lowers the scrum concentration of very low density lipoproteins (VLDL) through increasing the ratio of phospholipids to triacylglycerols. The content of saturated fatty acids in phospholipids is stable in relation to TAG, hence may be manifested as a higher perecntage of saturated fatty acids (C18:0) in total serum lipids. 
Content of fatty acids, \% and concentration of triacylglycerols (TAG) and total cholesterol (TCh), mmol/L in serum of rats, \%

TABLE 3

\begin{tabular}{|c|c|c|c|c|c|c|c|c|c|c|}
\hline \multicolumn{7}{|c|}{ Fceding groups } & \multicolumn{4}{|c|}{ ANOVA } \\
\hline \multirow[t]{3}{*}{ Items } & 1 & II & III & IV & V & $\mathrm{VI}$ & SEM & Fat & Lecithin & Fat $x$ Lccithin \\
\hline & \multicolumn{2}{|c|}{$\begin{array}{c}\text { Rape seed oil } \\
\text { RO }\end{array}$} & \multicolumn{2}{|c|}{$\begin{array}{l}\text { Linseed oil } \\
\text { LO }\end{array}$} & \multicolumn{2}{|c|}{$\begin{array}{l}\text { Fish oil } \\
\text { FO }\end{array}$} & & & & \\
\hline & - & Lecithin & - & Lecithin & - & Lecithin & & & & \\
\hline $\mathrm{C} 14$ & 1.51 & 2.26 & 1.41 & 1.29 & 1.61 & 1.99 & 0.18 & NS & NS & NS \\
\hline $\mathrm{Cl} 6: 0$ & 23.38 & $20.57^{a}$ & 22.43 & $20.0^{a}$ & 24.76 & $25.99^{\mathrm{b}}$ & 0.44 & $* *$ & NS & NS \\
\hline C16:1n-7 & 0.54 & $0.39^{b}$ & 0.38 & 0.35 & 0.27 & $0.26^{\mathrm{a}}$ & 0.03 & $*$ & NS & NS \\
\hline C16:1n-9 & 2.81 & $1.31^{\circ}$ & 2.42 & $1.91^{\mathrm{h}}$ & 3.07 & $2.45^{\mathrm{b}}$ & 0.11 & $*$ & $* *$ & NS \\
\hline C18:0 & 11.99 & $13.27^{\mathrm{a}}$ & 13.97 & $13.98^{\mathrm{h}}$ & 13.68 & $16.15^{\mathrm{h}}$ & 0.26 & $* *$ & $*$ & NS \\
\hline C18:1n-9 & 24.38 & $18.13^{h}$ & 16.78 & $12.59^{\mathrm{a}}$ & 15.31 & $19.02^{a}$ & 0.65 & $* *$ & NS & $* *$ \\
\hline $\mathrm{C} 18: \ln -7$ & 2.97 & $2.41^{\circ}$ & 2.02 & $1.59^{\mathrm{a}}$ & 2.37 & $2.07^{\mathrm{b}}$ & 0.05 & $* *$ & $* *$ & NS \\
\hline C18:2n-6 & 14.14 & $20.95^{b}$ & 15.95 & $22.84^{b}$ & 8.77 & $13.77^{\mathrm{a}}$ & 0.39 & $* *$ & $* *$ & NS \\
\hline C18:3n-3 & 1.71 & $1.59^{\mathrm{h}}$ & 5.27 & 4.6 & 0.76 & $0.73^{a}$ & 0.11 & $* *$ & NS & NS \\
\hline $\mathrm{C} 20: 0$ & 0.07 & 0.09 & 0.08 & 0.12 & 0.11 & 0.14 & 0.01 & NS & NS & NS \\
\hline $\mathrm{C} 20: 1 \mathrm{n}-9$ & 0.39 & 0.09 & 0.16 & 0.18 & 0.21 & 0.22 & 0.02 & NS & $*$ & $*$ \\
\hline$C 20: 2 n-6$ & 0.05 & 0.15 & 0.12 & 0.31 & 0.04 & 0.12 & 0.04 & NS & NS & NS \\
\hline$C 20: 3 n-3$ & 0.39 & $0.54^{4}$ & 0.67 & $0.68^{\mathrm{h}}$ & 0.30 & $0.41^{a}$ & 0.04 & $* *$ & NS & NS \\
\hline$C 20: 4 n-6$ & 11.39 & $15.35^{\mathrm{h}}$ & 8.23 & $11.19^{\mathrm{a}}$ & 9.07 & $7.05^{a}$ & 0.53 & $* *$ & NS & $*$ \\
\hline$C 20: 5 n-3$ & 1.47 & $0.99^{a}$ & 6.61 & $4.24^{b}$ & 11.74 & $4.47^{\circ}$ & 0.35 & $* *$ & $* *$ & $*$ \\
\hline C. $22: 5 n-3$ & 0.58 & $0.81^{\mathrm{s}}$ & 1.38 & $1.47^{\mathrm{h}}$ & 1.87 & $1.27^{\mathrm{h}}$ & 0.08 & $* *$ & NS & NS \\
\hline $\mathrm{C} 22: 6 \mathrm{n}-3$ & 2.01 & $1.94^{\circ}$ & 2.89 & $2.44^{2}$ & 5.92 & $3.81^{\mathrm{b}}$ & 0.17 & $* *$ & $* *$ & $*$ \\
\hline $\mathrm{Tg}$ & 1.57 & $0.72^{\mathrm{h}}$ & 0.67 & $0.7 I^{\mathrm{i}}$ & 0.55 & $0.32^{a}$ & 0.04 & $* *$ & $* *$ & $* *$ \\
\hline T.Ch. & 2.16 & $2.15^{\circ}$ & 2.03 & $1.81^{\mathrm{h}}$ & 1.91 & $1.43^{\mathrm{a}}$ & 0.82 & $* *$ & $* *$ & $*$ \\
\hline
\end{tabular}

${ }^{*}-\mathrm{P}<0.05 ;{ }^{*}-\mathrm{P}<0.01$, i. h.c $-\mathrm{P}<0.05$ between groups $\mathrm{RO}$ and $\mathrm{LO}, \mathrm{FO}$ 


\begin{tabular}{|c|c|c|c|c|c|c|c|c|c|c|}
\hline \multicolumn{11}{|c|}{ Content of fally acids in longissimus dorsi muscle of rats. $\%$} \\
\hline \multicolumn{7}{|c|}{ Feeding groups } & \multicolumn{4}{|c|}{ ANOVA } \\
\hline \multirow[t]{3}{*}{ Items } & 1 & II & iII & IV & $\mathrm{V}$ & VI & SEM & Fat & Lecithin & Fat $x$ Lecithin \\
\hline & \multicolumn{2}{|c|}{$\begin{array}{c}\text { Rape seed oil } \\
\text { RO }\end{array}$} & \multicolumn{2}{|c|}{$\begin{array}{l}\text { Linseed oil } \\
\text { LO }\end{array}$} & \multicolumn{2}{|c|}{$\begin{array}{c}\text { Fish oil } \\
\text { FO }\end{array}$} & & & & \\
\hline & - & Lecithin & - & Lecithin & - & Lecithin & & & & \\
\hline $\mathrm{C} 14$ & 1.49 & 1.64 & 1.80 & $2.13^{b}$ & 2.75 & $3.02^{\circ}$ & 0.07 & $* *$ & NS & $N S$ \\
\hline $\mathrm{C} 16: 0$ & 24.63 & 23.44 & 23.59 & $23.82^{\circ}$ & 26.85 & $26.79^{\mathrm{b}}$ & 0.27 & $* *$ & NS & NS \\
\hline C $16: \ln -7$ & 0.32 & 0.35 & 0.28 & 0.28 & 0.33 & 0.31 & 0.01 & NS & NS & NS \\
\hline $\mathrm{C} 16: \ln -9$ & 5.21 & $3.65^{\prime}$ & 6.01 & $5.85^{\mathrm{h}}$ & 7.83 & $6.80^{\circ}$ & 0.20 & $* *$ & $*$ & NS \\
\hline C 18:0 & 7.04 & 7.06 & 6.90 & 6.09 & 6.99 & 6.81 & 0.32 & NS & NS & NS \\
\hline $\mathrm{Cl} 8: \ln -9$ & 35.03 & $29.38^{h}$ & 27.59 & $25.11^{\lrcorner}$ & 26.54 & $22.47^{\circ}$ & 0.72 & $* *$ & $* *$ & NS \\
\hline C18: $\ln -7$ & 3.58 & $3.39^{\circ}$ & 2.66 & $2.34^{a}$ & 3.74 & $3.29^{\mathrm{h}}$ & 0.07 & $* *$ & $*$ & NS \\
\hline C18:2n-6 & 11.94 & 14.51 & 11.43 & 17.34 & 7.81 & 15.76 & 0.69 & NS & $* *$ & NS \\
\hline C18:3n-3 & 1.45 & $2.56^{\circ}$ & 10.96 & $11.00^{\mathrm{b}}$ & 0.96 & $1.59^{\mathrm{a}}$ & 0.33 & $* *$ & NS & NS \\
\hline $\mathrm{C} 20: 0$ & 0.13 & 0.14 & 0.22 & 0.13 & 0.13 & 0.13 & 0.02 & NS & NS & NS \\
\hline $\mathrm{C} 20: \ln -9$ & 0.59 & $0.70^{h}$ & 0.39 & $0.31^{a}$ & 0.41 & $0.42^{a}$ & 0.04 & $* *$ & NS & NS \\
\hline $\mathrm{C} 20: 2 \mathrm{n}-6$ & 0.72 & 0.14 & 0.08 & 0.13 & 0.16 & 0.11 & 0.01 & NS & NS & $\mathrm{NS}$ \\
\hline$C 20: 3 n-3$ & 0.26 & 0.25 & 0.32 & 0.23 & 0.28 & 0.27 & 0.02 & NS & NS & NS \\
\hline C20:4n-6 & 3.55 & $5.78^{\mathrm{b}}$ & 3.05 & $2.34^{\mathrm{b}}$ & 2.96 & $2.95^{\circ}$ & 0.29 & $*$ & NS & NS \\
\hline$C 20: 5 n-3$ & 0.27 & $0.27^{a}$ & 1.05 & $0.73^{h}$ & 1.56 & $1.47^{\circ}$ & 0.10 & $* *$ & NS & NS \\
\hline C.22:5n-3 & 1.25 & 1.03 & 1.86 & 1.39 & 1.46 & 1.29 & 0.11 & NS & NS & NS \\
\hline$C 22: 6 n-3$ & 2.96 & $3.49^{a}$ & 2.85 & $2.73^{\mathrm{t}}$ & 6.86 & $6.37^{\mathrm{h}}$ & 0.34 & $* *$ & NS & NS \\
\hline
\end{tabular}

$*-\mathrm{P}<0.05 ; * *-\mathrm{P}<0.01$, *. . $-\mathrm{P}<0.05$ between groups RO and LO, FO

$\stackrel{8}{\stackrel{9}{子}}$ 
On the basis of the results obtained on rats it can be stated that paimitic acid content does not affect the dietary properties of fish oil or lecithin. The hypercholesterolemic and hyperlipidemic properties of palmitic acid depend primarily on the quality and quantity of accompanying fatty acids, and also probably on the type of compound that they form and their position in it. Fatty acids occur in fats in the form of a mixture that is very characteristic of a specific type of fat, hence it scems that it is more appropriate to determine the dietary properties of a given type of fat rather than of a single fatty acid.

\section{Monounsaturated fatty acids (MUFA)}

In the I.d.m. as well as in serum (Tables 3 and 4) the oleic acid content was proportional to its percentage content in the diet. The lower percentage of $\mathrm{C} 18: 1$ $\mathrm{n}-9$ in the serum and tissues of rats receiving linseed and fish oils (Irie and Sakimoto, 1992) may have been the result of both the lower supply of this acid as well as the modifying action of PUFA $1-3$ from linseed and fish oils. PUFA can lower the MUFA content by inhibiting $\delta-9$ desaturase as well as by competing for sites in specific lipid structures (Jeffcoat, 1979). In another experiment the authors found a negative correlation between the serum and tissue MUFA and PUFA contents in rats receiving various types of fats in their diets (Sawosz et al., 1999).

In the serum and tissucs of those rats (with the exception of those receiving fish oil) that were fed lecithin-supplemented diets, a decline in the percentage of C18:1 $\mathrm{n}-9$ was observed. In this case it can be said that lowering the percentage of oleic acid was the result of a very high linoleic acid content in lecithin. The negative correlation between PUFA n-6 and n-9 MUFA was also reported by Leng et al. (1997).

Only in the scrum of animals fed fish oil did the addition of lecithin increase the C18:1 n-9 content. Cholesterol stored in the cell is preferentially esterified with olcic and linoleic acids (Nelson et al., 1997). When supplied in feed, fish oil may encourage the formation of cholesterol esters with long-chain n-3 PUFA. However, this process occurs much more slowly than esterification with $n-9$ and n-6 acids (Parks et al., 1989). At the same time, lecithin stimulates esterification of cholesterol. Most likely, in the case of considerable accumulation of long-chain n3 PUFA in phospholipids and the resulting relative deficiency of C18:2 n-6 and C18:3 n-3, in order to supply a substrate for cholesterol esterification, the synthesis of endogenous C18:1 n-9 increases.

In this experiment we also observed that the pereentage content of C16:1 n-9 in the serum of rats receiving various types of fats in their diets declined in response to the administration of lecithin. Lowering the level of this fatty acid in the serum was then more the result of inhibiting desaturase activity by linoleic acid from lecithin than competition between C16:1 n-9 and C18:2 n-6 for sites in serum lipids. Similar tendencies were observed in the case of C18:1 n-7. 
These results support the hypothesis that increased consumption of linoleic acid can modify the percentage of monounsaturated fatty acids. The diet-dependent serum level of MUFA did not show a relationship between these acids and the serum concentrations of TCh or TAG.

\section{Polyunsaturated fatty acids, $n-6$ PUFA}

The differentiated content of linoleic acid in the fats added to diets did not significantly affect the level of this acid in the l.d.m (Table 4). The lower percentage of linoleic acid in the scrum of rats fed fish oil resulted from the lower C18:2 $\mathrm{n}-6$ content in the oil (Table 3 ). Increasing the supply of linoleic acid by adding lecithin markedly enriched serum lipids and l.d.m. in this fatty acid. A rise in n-6 PUFA proportionately to its content in the diet was also observed by other authors (Ayre and Hulbert, 1997). Increasing the content of linoleic acid in the serum of rats fed rape seed and linseed oils plus lecithin occurred primarily through lowering the percentage of $\mathrm{C} 18: 1 \mathrm{n}-9$. Incorporation of linoleic acid into serum lipids of rats given fish oil took place at the expense of lowering the percentage of longchain PUFA, particularly those belonging to the n-3 family. It can therefore be supposed that the most prominent role among serum lipids is played by linoleic, $\alpha$-linolenic and oleic acids, followed by long chain n-3 PUFA.

During the experiment it was observed that serum from rats receiving rapeseed oil and linseed oil contained similar amounts of linoleic acid, while the content of arachidonic acid was lower in animals consuming linsecd oil. Arachidonic acid (C20:4 n-6), which is a precursor of, among others, $\mathrm{PGE}_{2}$ and $\mathrm{LTB}_{4}$, shows proinflammatory and pro-aggregational properties, in contrast with EPA, which is precursor of cicosatrienoids, including $\mathrm{LTB}_{5}$, which has anti-inflammatory properties (Zurier, 1993). Enriching tissues in arachidonic acid is not, therefore, a desired effect. Arachidonic acid is formed in tissues from linoleic acid through its desaturation ( $\delta$-6-desaturase), elongation and repeated desaturation ( $\delta$-5 desaturase). EPA is formed from $\mathrm{C} 18: 3 \mathrm{n}-3$ (from linseed oil) in a pathway catalyzed by the same enzymes. The ratio of C20:4 n-6 to C18:2 n-6 acids in the serum of rats fed rape seed oil was 0.8 , while in that of animals consuming linseed oil, 0.5. It may be presumed that desaturase may show a bit higher affinity to n-3 PUFA than to n-6 PUFA. Authors of other studies have also observed that compctition for $\delta-5$ desaturase led to inhibition of conversion of dihomo- $\gamma$-linolenic acid to arachidonic acid by conversion of C20:4 n-3 to EPA (Kinsela et al., 1990). Therefore, the addition of linsecd oil may decrease to a certain extent the synthesis of C20:4 n-6.

In the serum and l.d.m. of rats receiving rape secd oil and, to a lesser degrec, in the serum of animals fed linseed oil, an increase in the arachidonic acid content was observed in response to lecithin in the diet. Fish oil in the diet counteracted 
this rise in the serum of animals receiving lecithin. Long-chain fatty acids from the n-3 family probably inhibit the activity of $\delta-5$ or $\delta-6$ desaturase through a feedback mechanism, inhibiting the synthesis of EPA as well as arachidonic acid in this way.

The obtained results did not show a proportional relationship between the content of arachidonic acid or linoleic acid in the serum and the concentration of $\mathrm{TCh}$ and TAG.

\section{Polyunsaturated fatty acids, $n-3$ PUFA}

Both fish and linseed oil (linseed oil does not contain long-chain n-3 PUFA) (Table 2), significantly increased the percentage of EPA and its storage form, C22:5 $\mathrm{n}-3$, in serum. Most likely $\mathrm{C} 20: 5 \mathrm{n}-3$ is preferentially incorporated into serum lipids, particularly cholesterol, and less into muscle tissue (Bauer et al., 1997).

In this experiment we also found that the inclusion of only fish oil in the diet increased the DHA content of serum and muscle tissue (Tables 3 and 4; Calviello et al., 1997). Salem et al. (1996) showed that in children, the transformation of C18:3 n-3 into DHA is to a large extent ineffective, which confirms the presented results. Winters et al. (1994) observed that feeding rats $\alpha$-linolenic acid increased the EPA but not DHA concentrations in the serum. The author observed a higher DHA concentration in the liver, which he explains by an inherent difference between these two tissues in their ability to synthesize DHA in situ. The activity of liver desaturases may, however, affect the percentage of fatty acids in other tissues and scrum. It seems possible that both the level of $\delta$ - 4 desaturase activity that catalyzes the conversion of C22:5 n-3 to DHA in the liver, as well as the ability to selectively retain DHA in the tissues (Bauer et al., 1997) may be a determinant of the DHA content of muscle.

In our experiment we found that the addition of lecithin to the diet did not have a detrimental effect on the incorporation of n-3 PUFA into muscle tissue. We even observed a slight increase in $\mathrm{C} 18: 3 \mathrm{n}-3$ in the 1.d.m. This process can be explained by the antioxidative properties of lecithin (Kourimska et al., 1995). Nara et al. (1995) showed that phosphatidylcholine, which contains DHA in its molecule, particularly as 1,2-di-PUFA, may show a very strong protective effect on unsaturated fatty acids that could facilitate the accumulation of PUFA in tissues.

In contrast with 1.d.m., the serum contents of EPA and DHA declined in response to supplementation of the diet with lecithin. It was found that the percentage content of C18:2 n-6 and C18:1 n-9 increased in the place of EPA and DHA, which would point to the preferential incorporation of unsaturated 18 -carbon fatty acids into serum lipids over 20 - and 22 -carbon acids.

In this experiment we observed a significant interaction between dietary lccithin and fat with serum TAG and TCh concentrations. The addition of lecithin 
lowered the concentration of TCh only in the presence of PUFA n-3, particularly those having over eighteen carbons. The greatest decline in the TAG concentration was also observed under the influence of lecithin and long-chain n-3 PUFA.

Iwata et al. (1993) found that soyabean lecithin reduced cholesterol absorption in the small intestine, while Tateo et al. (1994) found that the addition of 5\% soyabean lecithin to the diet increased the excretion of TCh and lipids in faeces. In our experiment lecithin did not differentiate $\mathrm{TCh}$ in the serum of rats fed rape seed oil, which would support the hypothesis that serum TCh levels are related to increased elimination of TCh. Similar TAG concentrations in the serum of rats fed linseed oil with or without lecithin also pointed to the fact that lecithin did not lower TAG concentrations directly through eliminating lipids in faeces.

The addition of lecithin stimulates the synthesis of phospholipids (Ziegelitz, 1994), and in animals fed fish oil, leads to the formation of DHA-rich phospholipids. Docohexaenoic acid is conducive to the formation of cell membrane phospholipid domains low in cholesterol (Clamp et al., 1997). This acid is also not used preferentially in the formation of cholesterol esters by LCAT. In effect, it may lead to lowering the amount of cholesterol in membrane structures as well as in serum. Reducing the cholesterol content in ccll membranes and increasing the amount of DHA by using fish oil increases membrane fluidity and modifies their permeability. In effect this can lead to greater efficiency of lipid transport and metabolism in tissues. The physiological role of DHA-containing phosphatidylcholine is still not fully understood and remains the subject to be investigated.

\section{CONCLUSIONS}

The results of this study show that both the type of fat in the diet and the addition of lecithin very markedly affect the fatty acid content of rat muscles and serum. Tissue lipids enriched with n-3 PUFA, the long-chain fatty acids that animal and human diets are most deficient in, were found only in rats fed fish oil in their diets. In this case the addition of lecithin does not secm so important since the enrichment of tissues in linoleic acid in place of oleic acid (which was the only effect of the administered lecithin) can be achieved by consuming a diet rich in linoleic acid. However, analysis of serum lipid profiles shows that the addition of fish oil $(6 \%)$ and lecithin (5\%) to rat diets very significantly lowered cholesterol and triacylglyceride concentrations. Moreover, it seems that the above diet may be used in prevention of allergies due to the lower content of arachidonic acid. Although the addition of lecithin to the diet reduced the EPA and DHA levels in serum of animals given fish oil, it can be noticed that the proper site of efficient lecithin-independent accumulation of DHA is the tissue. 
The addition of lecithin to a diet can, therefore, be indicated in cases of dietary therapy, but lecithin does not seem to be indicated as a dietary supplement to modify muscle tissue composition.

\section{REFERENCES}

AOAC, 1990. Official Methods of Analysis of the Association of Official Analytical Chemists. 15th Edition, Chapter 32, Washington, DC

Ayre K.J., Hulbert A.J., 1997. Dietary fatty acid profile affects endurance in rats. Lipids 32, $1265-1270$

Bauer J.E., McAlister K.G., Rawlings J.M., Markwell P., 1997. Molecular species cholesteryl esters formed via plasma lecithin:cholesterol acyltransferase in fish oil supplemented dogs. Nutr. Res. $17,861-872$

Calviello G., Palloza P., Franceschelli P., Bartolli G.M., 1997. Low dose eicosapentaenoic or docosahexaenoic acid administration modifies fatty acid composition and does not affect susceptibility to oxidative stress in rat erythrocytes and tissues. Lipids $32,1075-1083$

Clamp A.G., Ladha S., Clark D.C., Grimble R.F., Lund E.K., 1997. The influence of dietary lipids on the composition and membrane fluidity of rat hepatocyte plasma membrane. Lipids 32 , 179-184

Fremont L., Gozzelino M. T., Hojjat T., 1995. Effects of moderate fat intake with different n-3 fatty acid sources and n-6/n-3 ratios on serum and structural lipids in rats. Reprod. Nutr. Develop. $35,503-515$

Gunther K.D., 1994. Lecithin , an active substance in animal nutrition. Kraftfutter 6, 213-217

Irie M., Sakimoto M., 1992. Fat characteristics of pigs fed fish oil containing eicosapentaenoic and cocosahexaenoic acids. J. Anim. Sci. 70, 470-47

Iwata T., Kimura Y., Tsutsumi K., Furukawa Y., Kimura S., 1993. The effects of various phospholipids on plasma lipoproteins and liver lipids in hypercholesterolemic rats. J. Nutr. Sci. Vitaminol. 39, 63-73

Jeffcoat R., 1979. The biosynthesis of unsaturated fatty acids and its control in mammalian liver. Essays Biochem. 15, 1-36

Jones D.B., Handcock J.D., Nelssen J.L., Hines R.H., 1990. Effect of lecithin and lisolecithin additions on growth performance and nutrient digestibility in weanling pigs. J. Anim. Sci. 68, 99-111

Jones D.B., Handcock J.D., Harmon D.L., Walker C.E., 1992. Effects of exogenous emulsifiers and fat sources on nutrient digestibility, serum lipids, and growth performance in weanling pigs. J. Anim. Sci. 70, 3473-3482

Kinsella J.E., Lokesh B., Broughton K.S., Whelan J., 1990. Dietary polyunsaturated fatty acids and eicosanoids: potential effects on the modulation of inflammatory and immune cells: an overview. Nutrition 5, 24-44

Kourimska L., Reblova Z., Pokorny J., Cevc G., Paltauf F., 1995. Stabilization of dietetic oils phospholipids against oxidative rancidity. Proceeding of the 6th International Colloquium, „Phospholipids: characterization, metabolism and novel biological applications”. Hamburg (Germany), 25-27 October 1993 
Leng G.C., Horrobin D.F., Smith F.B., Ells K., Morse-Fisher N., Fowkes F.G.R., 1997. Dietary nutrients and plasma n-3, n-6, saturated and monosaturated fatty acids. J. Nutr. Environ. Med. 7, 91-100

Loś-Kuczera, 1990. Food Products. Composition and Nutritive Value. Instytut Żywności i Żywienia, Warszawa, pp. 112

National Research Council, 1978. Nutrient Requirement of Laboratory Animals. National Academy of Science. Washington, DC

Nara E., Miyashita K., Ota T., 1995. Oxidative stability of PC containing linoleate and docosahexaenoate in an aqueous solution with or without chicken egg albumin. Biosci. Biotechnol. Biochem. 59, 2319-2320

Nelson G.J., Schmidt P.C., Bartdini G.L., Kelly D.S., Kyle D., 1997. The effects of dietary docosahexaenoic acid on plasma lipoproteins and tissue fatly acid composition in humans. Lipids 32, 1137-1146

Overland M.. Tokach M.D.. Cornelius S.G., Pettigrew J.E., Rust J.W., 1993, Lecithin in swine diets: II. Growing-finishing pigs. J. Anim. Sci. 71, 1194-1197

Parks J.S., Bullock B.C., Rudel L.L., 1989. The reactivity of plasma phospholipids with lecithin: cholesterol acyltransferase is decreased in fish oil-fed monkeys. J. Biol. Chem. 5, 2545-2551

Salem N.J., Wegner B., Mena P., Vany R., 1996. Arachidonic and docosahexaenoic acids are biosynthesised from their 18-carbon precursor in human infant. Proc. Nat. Acad. Sci., USA 93 , $49-54$

Sawosz E., Chachutowa J., Lechowski R., Fiedorowicz Sz., 1996. Influence of supplement of lecithin on lipids metabolism in rats (in Polish). Proceeding of the XXVI Conference of $\Lambda$ nimal Nutrition Board, Committee on Animal Sciences, Olsztyn (Poland), pp. 181-184

Sawosz E.. Chachułowa J., Lechowski R., Ficdorowicz. Sz., Kosieradzka I., 1999. Effect of different dietary fats on percentage content of fatty acids in the blood serum and in the longissimus dorsi muscle of rats. J. Anim. Feed Sci. 8, 95-105

Smith D.R., Knabe D.A., Gross H.R., Smith S.B. 1996. A diet containing myristoleic plus palmitoleic acid elevates plasma cholesterol in young growing swine. Lipids 37, 849-858

Tateo M., Yoshikawa M., Takeuchi H., Fujii S., Mizobuchi H., Takeuchi H., 1994. Etfects of sterylglycosides from soybean on lipid indices in the plasma, liver and faeces of rats. Biosci. Biotechnol. Biochem. 58, 494-497

Winters B.L.. Yeh S.M., Yeh Y.Y., 1994. Linolenic acid provides a source of docosahexaenoic acid for artificially reared rat pups. J. Nutr. 124, 1644- I654

Yu S., Derr J., Etherton T.D., Kris- Ethrton P.M., 1995. Plasma cholesterol predictive equations demonstrate that stearic acid is neutral and monounsaturated fatty acids are hypocholesteroenic. Amer. J. Clin. Nutr. 61, 1129-1139

Ziegelitz R., 1994. The use of phospholipids and their derivatives to increase fat utilization in animal diets. Proceedings of the International Animal Nutrition Symposium: Updating the Use of Animal Byproducts in Animal Feeds. Utrecht (Netherlands), pp. 58-68

Zurier R.B.. 1993. Falty acids, an1lammation and immune response. Prostagland. Leuk. Essent. Fatty $48,57-62$ 


\section{STRESZCZENIE}

Wplyw dodatku do diety lecytyny i tłuszczów o zwiększonej zawartości wielonienasyconych kwasów tluszczowych (PUFA) n-3 na procentową zawartość kwasów tluszczowych w mięśniu i surowicy krwi szczurów

Czterdzieści osiem szczurów (Wistar), podzielonych na 3 grupy, żywiono dietami półsyntetycznymi zawierajacymi różne rodzaje tłuszczu (6\%): olej rzepakowy, lniany lub rybny. Połowa zwierząt w każdej grupie otrzymywała dodatek lecytyny ( $5 \%$ mieszanki). W doświadczeniu określono procentową zawartość kwasów tłuszczowych w surowicy oraz mięśniu najdłuższym grzbietu, a także zawartość triacylogliceroli (TAG) i cholesterolu całkowitego (TCh) w surowicy. Stwierdzono, że podawanie oleju rybnego wpłynęło na zwiększenie procentowej zawartości kwasu eikozapentaenowego (EPA) i dokozaheksaenowego (DHA) w surowicy i tkance mięśniowej, natomiast dodatek oleju lnianego powodował zwiększenie zawartości kwasu a-linolenowego oraz EPA w badanych tkankach. Dodatek lecytyny wpłynął na zwiększenie procentowej zawartości kwasu linolowego w surowicy i tkance oraz zmniejszenie zawartości EPA i DHA w surowicy. Koncentracja TAG i TCh była znacznie mniejsza u zwierząt otrzymujących w mieszankach dodatek lecytyny i oleju rybnego, a także w mniejszym stopniu oleju lnianego niż u szczurów otrzymujących olej rzepakowy. 